\title{
Assessment of trace metal contamination of soil in a landfill vicinity: A southern Africa case study
}

\author{
Joan Nyika $^{a^{*}}$, Ednah Onyaria $^{a}$, Megersa Dinka ${ }^{\mathrm{b}}$ and Bhardwaj Shivanic
}

${ }^{a}$ University of South Africa, Department of Civil and Chemical Engineering, University of South Africa [Florida science campus], Cnr Christian de Wet Road and Pioneer Avenue, Johannesburg, South Africa

${ }^{b}$ University of Johannesburg, Department of Civil Engineering Science, University of Johannesburg, APK Campus 2006, Johannesburg, South Africa ${ }^{c}$ University of South Africa, Nanotechnology and Water Sustainability Unit, University of South Africa [Florida science campus], Cnr Christian de Wet Road and Pioneer Avenue, Johannesburg, South Africa

\section{H R O N I C L E}

Article history:

Received October 8, 2019

Received in revised form

November 21, 2019

Accepted February 18, 2020

Available online

February 18, 2020

Keywords:

Contamination

Landfill

Trace metals

Indices

Pollution

Soil

\begin{abstract}
A B S T R A C T
Contamination of soils by trace elements is a worldwide concern and has negative effects on environmental sustainability. Geochemical assessment of soils using appropriate indicators and pollution indices has received much attention in recent years in efforts to rehabilitate this resource. This study quantified pollution of soils by trace elements at the Roundhill landfill, South Africa using indices and multivariate statistics. Soils were collected and assayed for trace metals using x-ray fluorescence. Pollution indices classified soil contamination levels while multivariate statistical analysis was conducted using principal component and cluster analyses. Findings showed that concentrations of all elements decreased with increasing distance from the landfill. Low to extremely high pollution was evident in all soils and $\mathrm{Cr}$ had the highest values compared to other elements. Negative correlation and weak clustering of $\mathrm{Cr}$ and Cd was associated with different wastes disposed at the landfill. Reported pollution in soils was associated with the influence of landfill leachate in the investigated area.
\end{abstract}

(C) 2020 Growing Science Ltd. All rights reserved.

\section{Introduction}

Soils contain trace metals that are important nutrient components, but can be toxic at elevated levels. These elements are derivatives of lithologic transformations and anthropogenic pollution. Concerns on contamination of soils by trace elements are on the rise although the mechanisms of assessing the pollution levels precisely are limited. ${ }^{1-2}$ These concerns are justified by the complex nature of soils, which enhances adsorption of disposed pollutants resulting to adverse environmental effects. ${ }^{3}$ Soils in addition act as medium to transmit pollutants to water resources, plants and atmosphere through diffusive and dispersive movements, which result to bioaccumulation, phytoaccumulation and geoaccumulation. ${ }^{4}$

In sub-Saharan Africa, trace metal pollution in soils is a common phenomenon in vicinities of hotspots such as mines, landfills, urban and industrial zones. ${ }^{5}$ In South Africa, soil pollution from * Corresponding author. Tel: +27644939499 
landfill leachate is widespread since many of the country's cities generate waste equivalent to that of developed countries, most of which is disposed. However, more than $90 \%$ of the waste is landfilled unscientifically and becomes a pollution threat to soils. ${ }^{6}$ Urbanization and industrialization have worsened the state, as solid waste generation exceeds the management capacity. ${ }^{7}$ The use of pollution indices to assess contamination levels is a solution to land clean-up and pollution control. ${ }^{8}$ These indices are suitable geochemical indicators of extents, hotspots and sources of pollution. Additionally, they estimate environmental and ecological risks associated with pollution and distinguish lithologic sources from human-propagated pollution. ${ }^{9-10}$ Single indices such as geoaccumulation index (Igeo), contamination factor (CF), pollution degree (PD) and pollution load index (PLI) are examples of such indices. ${ }^{11}$ They classify soils based on predetermined metal background levels and provide information on its sustainability. ${ }^{12}$ Combined with multivariate studies, pollution indices explain trace metal occurrence, processing and multidimensionality. ${ }^{13-14}$ This study aimed at analysing the contamination by trace metals in soils of Roundhill landfill vicinity in Southern Africa using pollution indices and multivariate statistics.

\section{Results and Discussion}

\subsection{Trace Metal Content of soils}

The descriptive statistics of assayed trace elements of various sampling sites are presented in Table 1. The means of all trace elements exceeded the background levels (Table 6) with exception of Co and $\mathrm{Zn}$. This observation suggested that sampled soils were contaminated. Of all the assayed metals, the mean concentration of $\mathrm{Cr}$ was the highest compared to $\mathrm{Pb}$ that was the lowest. High $\mathrm{Cr}$ levels even in the reference site could be associated to lithologic contribution of the element. A geologic survey conducted in the area confirmed, that its rocks are ultra-mafic and have high levels of $\mathrm{Cr}^{15}$ The values of standard deviation $(S D)$ ranged from 34 to $688 \mathrm{mg} \mathrm{kg}^{-1}$, which depicts great dispersion of concentrations at various sampling sites. The values of the coefficient of variation $(\mathrm{CV})$ confirmed the great spread of trace element concentrations. Lower values of standard errors $(S E)$ in $\mathrm{Cd}, \mathrm{Cu}, \mathrm{Pb}$ and $\mathrm{Zn}$ showed a high reliability of their means compared to other trace elements.

Table 1. Mean concentrations $\left(\mathrm{mg} \mathrm{kg}^{-1}\right)$ and descriptive values for the tested metals at different sampling sites

\begin{tabular}{|c|c|c|c|c|c|c|c|c|}
\hline \multirow[t]{2}{*}{ SitelParameter } & $\mathrm{Cd}$ & $\mathrm{Co}$ & $\mathrm{Cr}$ & $\mathrm{Cu}$ & $\mathrm{Ni}$ & V & $\mathrm{Pb}$ & $\mathrm{Zn}$ \\
\hline & \multicolumn{8}{|c|}{$\left(\mathrm{mg} \mathrm{kg}^{-1}\right)$} \\
\hline L0 & 154 & 365 & 1039 & 293 & 500 & 600 & 110 & 246 \\
\hline L50 & 102 & 378 & 955 & 240 & 345 & 502 & 49.2 & 136 \\
\hline L100 & 76 & 318 & 957 & 130 & 253 & 465 & 18.9 & 94 \\
\hline L250 & 43 & 267 & 873 & 192 & 286 & 361 & 6.5 & 133 \\
\hline L500 & 12 & 544 & 1178 & 170 & 468 & 615 & 71 & 94 \\
\hline West1 & 111 & 209 & 1365 & 81 & 281 & 308 & 48.4 & 124 \\
\hline West2 & 91 & 75 & 2997 & 192 & 264 & 293 & 64.4 & 120 \\
\hline East1 & 13 & 439 & 905 & 202 & 333 & 272 & 44.2 & 132 \\
\hline Ref. & 3 & 49 & 757 & 162 & 225 & 100 & 2.5 & 94 \\
\hline Min & 3 & 49 & 757 & 81 & 225 & 100 & 2.5 & 94 \\
\hline Max & 154 & 544 & 2997 & 293 & 500 & 615 & 110 & 246 \\
\hline Mean $\left(\mathrm{mg} \mathrm{kg}^{-1}\right)$ & 67 & 294 & 1225 & 185 & 328 & 391 & 46 & 130 \\
\hline SD & 52 & 163 & 688 & 61 & 96 & 169 & 34 & 47 \\
\hline $\mathrm{SE}$ & 17 & 54 & 229 & 20 & 32 & 56 & 11 & 16 \\
\hline CV (\%) & 78 & 55 & 56 & 33 & 29 & 43 & 74 & 36 \\
\hline
\end{tabular}




\subsection{Values of Pollution Indices and Contamination Classes}

Pollution indices calculated from trace metal concentrations of sampling sites (Table 1) and classification of soils at these sites are presented in Table 2. Contamination factor $(C F)$, levels of $\mathrm{Cr}$ at all sampling sites were elevated compared to other trace metals. About $49 \%$ of the total calculated CF values revealed very high contamination at the sampling sites by the trace metals. There was no pollution due to $\mathrm{Zn}$ and contamination by Co was low in most sampling sites. The CF values of all elements in areas close to the landfill (L0, L50, L100, West 1, and West 2) were higher compared to the other sampling sites. This could arise due to high leachate concentration and its subsequent horizontal migration. In Ariyamangalan landfill of India, CF values of sampling sites decreased with increasing distance from the dumpsite due to the dispersive movement of leachate. ${ }^{16}$

Table 2. Contamination factor $(C F)$ and geoaccumulation $\left(I_{g e o}\right)$ index values of trace elements at sampling sites and classification of soils

\begin{tabular}{lllllllll|llllllll}
\hline \multicolumn{1}{c}{} & $\mathrm{Cd}$ & $\mathrm{Co}$ & $\mathrm{Cr}$ & $\mathrm{Cu}$ & $\mathrm{Ni}$ & $\mathrm{V}$ & $\mathrm{Pb}$ & $\mathrm{Zn}$ & $\mathrm{Cd}$ & $\mathrm{Co}$ & $\mathrm{Cr}$ & $\mathrm{Cu}$ & $\mathrm{Ni}$ & $\mathrm{V}$ & $\mathrm{Pb}$ & $\mathrm{Zn}$ \\
L0 & 20.5 & 1.2 & 159.9 & 18.3 & 5.5 & 4.0 & 5.5 & 1.0 & 4.1 & 0.2 & 32.0 & 3.7 & 1.1 & 0.8 & 1.1 & 0.2 \\
L50 & 13.6 & 1.3 & 146.9 & 15.0 & 3.8 & 3.4 & 2.5 & 0.6 & 2.7 & 0.3 & 29.4 & 3.0 & 0.8 & 0.7 & 0.5 & 0.1 \\
L100 & 10.1 & 1.1 & 147.2 & 8.1 & 2.8 & 3.1 & 1.0 & 0.4 & 2.0 & 0.2 & 29.5 & 1.6 & 0.6 & 0.6 & 0.2 & 0.1 \\
L250 & 5.7 & 0.9 & 134.3 & 12.0 & 3.1 & 2.4 & 0.3 & 0.6 & 1.2 & 0.2 & 26.9 & 2.4 & 0.6 & 0.5 & 0.1 & 0.1 \\
L500 & 1.6 & 1.8 & 181.2 & 10.6 & 5.1 & 4.1 & 3.6 & 0.4 & 0.3 & 0.4 & 36.3 & 2.1 & 1.0 & 0.8 & 0.7 & 0.1 \\
West1 & 14.8 & 0.7 & 210.0 & 5.1 & 3.1 & 2.1 & 2.4 & 0.5 & 3.0 & 0.1 & 42.0 & 1.0 & 0.6 & 0.4 & 0.5 & 0.1 \\
West2 & 12.1 & 0.3 & 461.1 & 12.0 & 2.9 & 2.0 & 3.2 & 0.5 & 2.4 & 0.1 & 92.2 & 2.4 & 0.6 & 0.4 & 0.6 & 0.1 \\
East1 & 1.7 & 1.5 & 139.2 & 12.6 & 3.7 & 1.8 & 2.2 & 0.6 & 0.4 & 0.3 & 27.9 & 2.5 & 0.7 & 0.4 & 0.4 & 0.1 \\
Ref. & 0.4 & 0.2 & 116.5 & 10.1 & 2.5 & 0.7 & 0.1 & 0.4 & 0.1 & 0.0 & 23.3 & 2.0 & 0.5 & 0.1 & 0.0 & 0.1 \\
\hline
\end{tabular}

Geoaccumulation index $\left(I_{g e o}\right)$ values of various trace elements ranged from not-polluted in $\mathrm{Zn}$ to extremely contaminated in $\mathrm{Cr}$ and were all lower compared to the $C F$ values, since the index has a constant to reduce trace element contribution from lithologic sources. The Igeo values of this study depict the influence of landfill leachate on trace elements concentrations in soils. A similar observation was made in a trace metal pollution assessment of soils in Tamilnadu landfill (India), whereby high $I_{g e o}$ values were attributable to leachate contamination. ${ }^{17}$ The indiscriminate disposal of metal containing solid waste at the landfill such as electronic waste, ash, scrap metal, building and demolition wastes could be associated with high $C F$ and $I_{g e o}$ values. The dumping of coalmine waste containing trace metals in Jorong area of Indonesia was correlated to high values of these pollution indices. ${ }^{18}$ Open dumping of solid waste and generation of landfill leachate was associated with high $C F$ and Igeo values in a study evaluating trace metals at Tianjin landfill, China. ${ }^{19}$

Pollution load index (PLI) and pollution degree (PD) levels of all sampling sites were calculated to assess soil toxicity due to the assayed contaminants and results were as shown in Table 3. The PLI values revealed the presence of pollution in soils from all trace metals with exception of Co and $\mathrm{Zn}$ whose levels were $<1$. Similarly, all elements caused very high pollution degrees in soils with exception of $\mathrm{Co}$ and $\mathrm{Zn}$ that had moderate and low contamination levels, respectively. A study of soils from a landfill near the Nile Delta, Egypt revealed very high contamination and both PLI and $P D$ values were $>1$ and $>28$, respectively. ${ }^{20}$

Table 3. Pollution load index (PLI) and pollution degree (PD) values of soils at different depths

\begin{tabular}{lllllllll}
\hline Parameter & $\mathrm{Cd}$ & $\mathrm{Co}$ & $\mathrm{Cr}$ & $\mathrm{Cu}$ & $\mathrm{Ni}$ & $\mathrm{V}$ & $\mathrm{Pb}$ & $\mathrm{Zn}$ \\
\hline PLI & 5.1 & 0.8 & 102.8 & 8.6 & 3.1 & 2.1 & 1.4 & 0.6 \\
PD & 93.1 & 8.8 & 1696.3 & 103.9 & 32.5 & 23.4 & 20.8 & 4.9 \\
\hline
\end{tabular}




\subsection{Multivariate Statistics of the Heavy Metals}

Inter-elemental relationships of trace elements using Pearson's correlation coefficient were as shown in Table 4. They were calculated from the metal concentrations shown in Table 1. Co-Ni, Co$\mathrm{V}, \mathrm{V}-\mathrm{Ni}, \mathrm{Ni}-\mathrm{Pb}$ and $\mathrm{Cu}-\mathrm{Zn}$ had strong positive correlation, which could point to the elements having similar waste sources. Electronic, ash, plastic and paper wastes at the landfill site could have contributed to the observed correlation of $\mathrm{Cu}$ and $\mathrm{Zn}$. A similar study established these wastes as sources of $\mathrm{Cu}$ and $\mathrm{Zn}$ from dumpsites. ${ }^{21}$ Treated health wastes, electronics and metal scrap disposed in Roundhill landfill could be common sources of $\mathrm{Co}, \mathrm{V}, \mathrm{Ni}$ and $\mathrm{Pb}$. In Baotou area of China, dumping of electronic and health wastes was attributed to the accumulation of $\mathrm{Co}, \mathrm{V}, \mathrm{Ni}$ and $\mathrm{Pb}^{22}$ Strong positive correlations of $\mathrm{Cr}, \mathrm{Cu}, \mathrm{Ni}, \mathrm{Pb}$ and $\mathrm{Zn}$ were attributed to similar origin and geochemical affinities in a heavy metal assay of Chinese grassland soils. ${ }^{23}$ Industrial waste disposal in Kayseri region of Turkey was associated to strong positive correlation between $\mathrm{Cu}-\mathrm{Zn}$ and $\mathrm{Co}-\mathrm{Ni}^{2}{ }^{24}$

Chromium $(\mathrm{Cr})$ had a weak or negative correlation with all other elements, suggesting different origin, which could include chemical plants in the area, leather tanning, electroplating and textile wastes disposed in the landfill. Weak negative correlation of $\mathrm{Cr}$ with $\mathrm{Co}, \mathrm{Cu}$ and $\mathrm{Zn}$ was attributed to agricultural and industrial sources in a trace element analysis of soils at Mersin Province of Turkey. ${ }^{25}$ Cadmium weakly correlated with other trace elements, a trend that could arise due to different sources of wastes such as pigments and plastics. A similar trend was reported in Brazilian soils, where Cd had weak correlations with $\mathrm{Cr}, \mathrm{Co}, \mathrm{Cu}, \mathrm{Fe}, \mathrm{Mn}$ and $\mathrm{Zn}$ due to different sources of the element. ${ }^{26}$

Table 4. Pearson's correlation between trace metal concentrations at different sampling sites

\begin{tabular}{lllllllll}
\hline Variables & $\mathrm{Co}$ & $\mathrm{Cr}$ & $\mathrm{Cu}$ & $\mathrm{Ni}$ & $\mathrm{V}$ & $\mathrm{Zn}$ & $\mathrm{Pb}$ & $\mathrm{Cd}$ \\
\hline $\mathrm{Co}$ & 1 & -0.420 & 0.283 & $\mathbf{0 . 7 3 5}$ & $\mathbf{0 . 7 5 2}$ & 0.174 & 0.398 & -0.072 \\
$\mathrm{Cr}$ & -0.420 & 1 & -0.056 & -0.154 & -0.107 & -0.059 & 0.326 & 0.273 \\
$\mathrm{Cu}$ & 0.283 & -0.056 & 1 & 0.601 & 0.409 & $\mathbf{0 . 7 3 7}$ & 0.529 & 0.299 \\
$\mathrm{Ni}$ & $\mathbf{0 . 7 3 5}$ & -0.154 & 0.601 & 1 & $\mathbf{0 . 8 0 5}$ & 0.618 & $\mathbf{0 . 8 2 0}$ & 0.271 \\
$\mathrm{~V}$ & $\mathbf{0 . 7 5 2}$ & -0.107 & 0.409 & $\mathbf{0 . 8 0 5}$ & 1 & 0.408 & 0.639 & 0.426 \\
$\mathrm{Zn}$ & 0.174 & -0.059 & $\mathbf{0 . 7 3 7}$ & 0.618 & 0.408 & 1 & 0.688 & 0.691 \\
$\mathrm{~Pb}$ & 0.398 & 0.326 & 0.529 & $\mathbf{0 . 8 2 0}$ & 0.639 & 0.688 & 1 & 0.591 \\
$\mathrm{Cd}$ & -0.072 & 0.273 & 0.299 & 0.271 & 0.426 & 0.691 & 0.591 & 1 \\
\hline
\end{tabular}

Values in bold are different from 0 with a significance level $\alpha=0.95$

Results of the transformed data of trace elements after principal component analysis $(P C A)$ are presented in Fig. 1. The transformation resulted to eight factor loadings $(F 1-F 8)$ with Eigen values of $4.1,1.8,1.0,0.6,0.3,0.1,0.05$ and 0.005 contributing to $52,22,12,8,4,1,0.6$ and $0.06 \%$ of total variability in respective order. However, the study focused on the first two factor loadings that contributed to approximately $75 \%$ of total variability. The correlation of trace elements showed close linkages between $\mathrm{Cu}-\mathrm{Zn}, \mathrm{Ni}-\mathrm{V}, \mathrm{Cu}-\mathrm{Pb}$ and $\mathrm{Pb}-\mathrm{Zn}$ based on their narrow angles. Close elemental linkages represented with narrow angles could be because of a common pollution source as reported in a similar heavy metal correlation analysis in soils of Islamabad area of Pakistan. ${ }^{27}$ Cadmium-Co and $\mathrm{Co}-\mathrm{Zn}$ axes formed right angles and were unrelated while $\mathrm{Cr}$ and $\mathrm{Cd}$ were unrelated with all other elements. Cadmium, $\mathrm{Co}, \mathrm{Cu}, \mathrm{Ni}, \mathrm{Pb}, \mathrm{V}$ and $\mathrm{Zn}$ were related to the first factor loading, while the second factor loading best represented $\mathrm{Cr}$ correlation. These observed weak positive and strong negative associations of trace elements were attributable to different pollution origins as established in a trace metal analysis of agricultural soils in Peloponnese, (Greece) using a similar approach. ${ }^{12}$ 


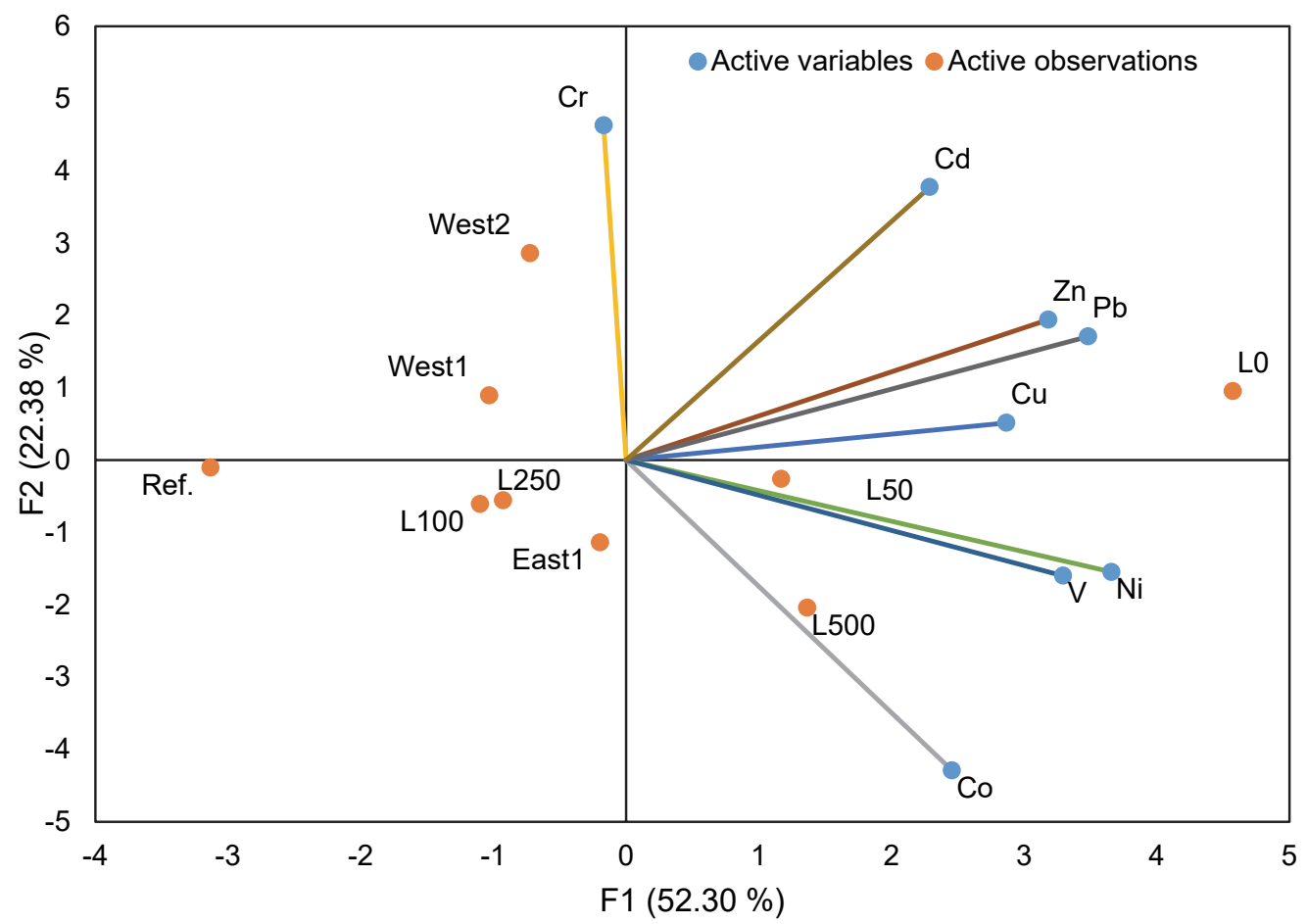

Fig. 1. Biplot showing the relationships between active variables and active observations

These results were consistent with Pearson's correlation. Additionally, they agreed with cluster analysis results (Fig. 2a) that showed four groups of trace elements; one with $\mathrm{Cd}$, another $\mathrm{Cr}$, another with $\mathrm{Cu}$ and $\mathrm{Zn}$ and a last one with $\mathrm{Co}, \mathrm{Ni}, \mathrm{Pb}$ and $\mathrm{V}$. The analysed trace elements in this study had different relationships unlike a trace metal assessment at Khulna landfill (Bangladesh) vicinity, where all elements had close geochemical affinities. ${ }^{28}$ A cluster analysis of sampling sites is shown in Fig. 2b. L0 and West 2 sampling sites were unique from the others. This could be consistent with results of Table 4, whereby, L0 had high levels of $\mathrm{Cd}, \mathrm{Cu}, \mathrm{Pb}$ and $\mathrm{Zn}$ while the West 2 had the highest concentration of $\mathrm{Cr}$. The other sampling sites had relatively the same trace metal concentration trends hence they clustered together.

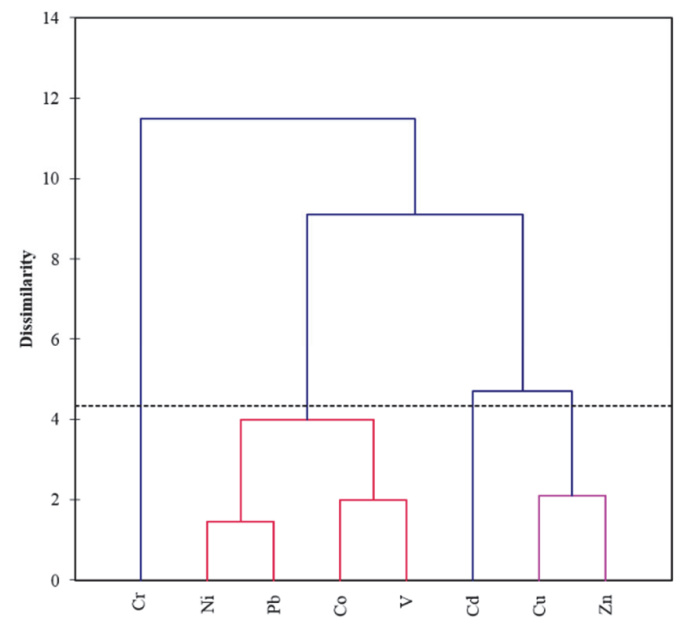

a)

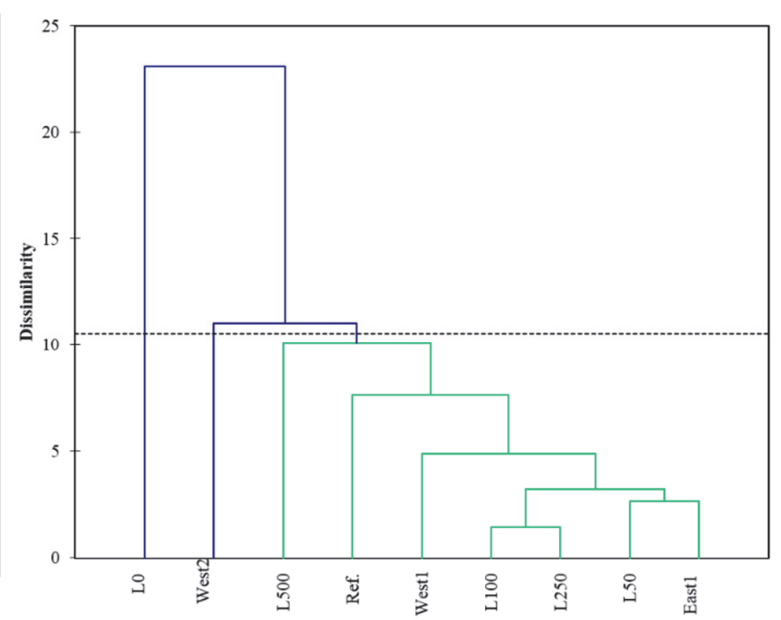

b)

Fig. 2. Dendrograms showing agglomerate hierarchical clustering results of a) trace elements and b) sampling sites 


\section{Conclusions}

In this study, pollution indices were calculated using assayed concentrations of trace metals and their background levels to classify soils based on their contamination levels. Multivariate statistical analyses were used to correlate observed soil pollution to different solid wastes of Roundhill landfill and resultant leachate. In conclusion, leachate from the landfill had great influence on pollution of investigated soils.

\section{Acknowledgements}

The authors are grateful to the University of South Africa for the support offered towards completing this research

\section{Materials and Methods}

\subsection{Study Area}

Roundhill landfill is located in Buffalo city municipality of South Africa's Eastern Cape Province (latitude 320 $53^{\prime} 13.66^{\prime \prime S}$ and longitude 27037'26.20"E), (Fig. 3). The site covers 56 hectares, has a $3.5^{0}$ slope towards the north-and-south-east and was previously a natural grassland for grazing. The landfill receives approximately 500 tonnes of general (business, domestic, building and demolition wastes) and treated healthcare wastes daily. ${ }^{29}$ At its commissioning in 2006, the facility was covered with a geomembrane liner that has undergone extensive damage and become inadequate due to waste increments. ${ }^{30}$ Existing leachate management system was insufficient characterized by leakages, runoffs and no connection to a wastewater treatment plant although the area has positive water balance. In response to these inadequacies, a temporary landfill cell consisting of a protection layer, a compacted clay liner and leachate collection system have been installed and rehabilitation is underway. ${ }^{29}$

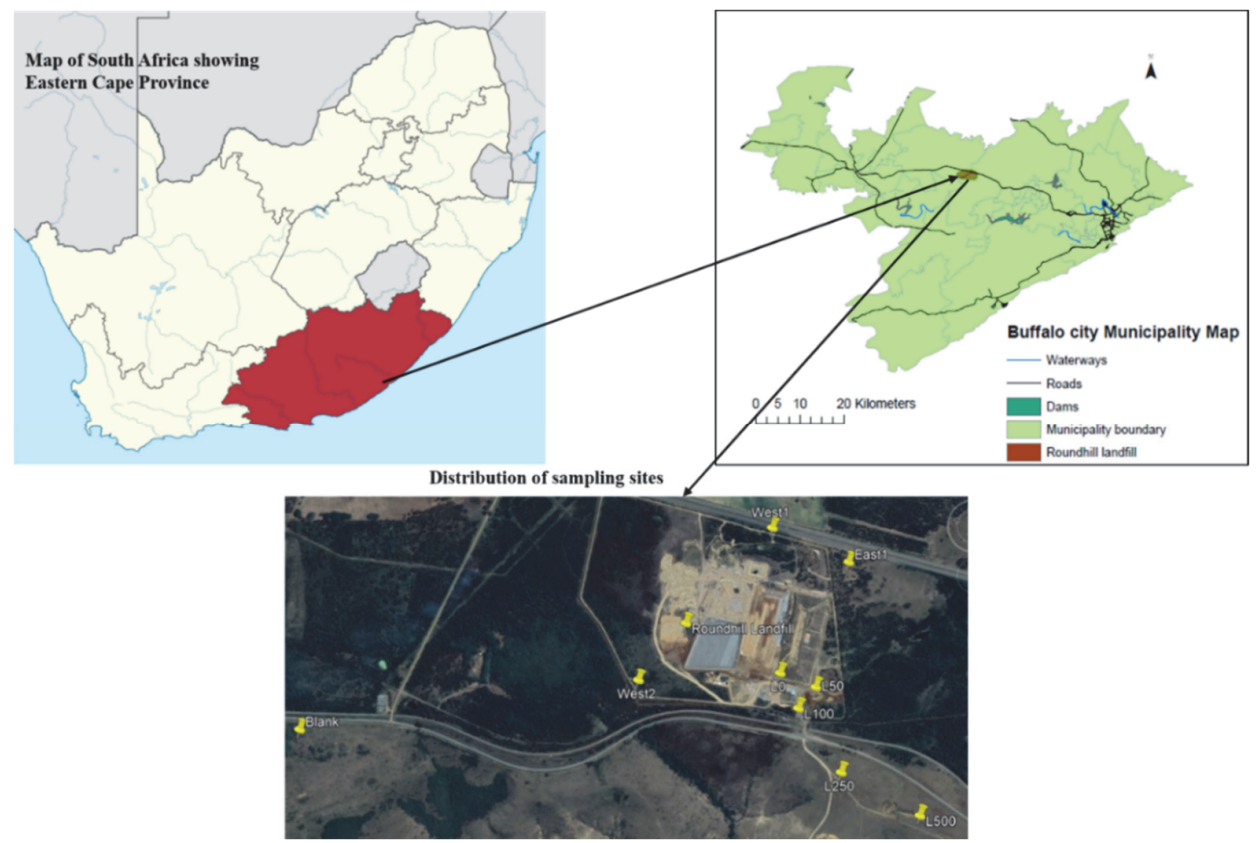

Fig. 3. Location of the study area and distribution of sampling sites

Area climate is temperate and warm with a mean temperature of $21^{\circ} \mathrm{c}$, evaporation and rainfall levels ranging from $160-170 \mathrm{~mm} / \mathrm{month}$ and $400-1000 \mathrm{~mm} /$ year, respectively. ${ }^{31}$ Area soils have high clayey content, which was one of the factors that made the location suitable for landfill construction. These soils accumulate trace elements due to their strong adsorptive properties. Soils in the area have low 
organic matter content due to high temperatures that enhanced decomposition. ${ }^{29-30}$ The study area has a minor aquifer system with a groundwater depth greater than $40 \mathrm{~m}$ and a low groundwater potential, as the yields of boreholes are below $1 \mathrm{~L} / \mathrm{s}$. Low vertical permeability and lateral movement of groundwater is associated to the clayey nature of area soils. ${ }^{31}$

\subsection{Soil Sampling and Analysis}

Soils were collected from 8 sampling sites namely; L0, L50, L100, L250, L500, West 1, West 2 and East 1 and a reference site (Ref.) two kilometres from the landfill facility (Fig. 3). A convenience sampling approach, whereby only sampling points, which were accesible to the researcher was used due to the harsh terrain of the landfill vicinity that was bushy, rocky and was steep. This method is suitable in studies, where locating the population is difficult and the geographic distribution of research elements is out of the researcher's proximity. ${ }^{32-33}$ At each sampling site, soils were collected at three depths; 30, 60 and $100 \mathrm{~cm}$ to represent topsoil, subsoil 1 and subsoil 2, respectively. A total of twentyseven samples were collected and transferred to polyethene bags, sealed and labelled for analysis. Prior to analysis, they were oven-dried at $105^{\circ} \mathrm{C}$ for 12 hours to minimize systematic bias and physical interferences on the $\mathrm{x}$-ray fluorescence $(X R F)$ signal, which result from the presence of soil moisture. $^{34}$

The dry soil samples were ground in an agate mortar and pestle and sieved with a 75 -micron sieve to reduce matric effects during analysis. Loss on Ignition (LOI) analysis was done by burning about 30 $\mathrm{g}$ of each soil sample in crucibles at $950^{\circ} \mathrm{c}$ for 2 hours to remove their volatile substances. Soils were further pulverized to get a representative sample before their manual pressing using a hydraulic press. Concentrations of trace elements were determined using a sequential XRF spectrometer ( $P W$ 2404, Phillips, Holand). Equipment calibration was conducted using reference materials of predetermined intensities. Each soil sample was prepared in triplicates, placed on sterile carriers and mounted in the equipment cassette for analysis. Assayed trace metals included cadmium (Cd), cobalt (Co), chromium $(\mathrm{Cr})$, copper $(\mathrm{Cu})$, lead $(\mathrm{Pb})$, nickel $(\mathrm{Ni})$, vanadium $(\mathrm{V})$ and zinc $(\mathrm{Zn})$.

\subsection{Chemical Characteristics of Leachate}

Leachate was suspected to be the pollutant source in the vicinity of Roundhill landfill. A sample was collected from an open pond next to the landfill and analysed for chemical qualities. The results were as shown in Table 5.

Table 5. Chemical characteristics of leachate

\begin{tabular}{lll}
\hline Parameter & Unit & value \\
\hline $\mathrm{pH}$ & - & $8.4^{*}$ \\
\hline Electrical conductivity & $\mathrm{mS} \mathrm{m}^{-1}$ & 1661 \\
\hline Total dissolved solids & & 8990 \\
\hline Chemical oxygen demand & & 2600 \\
\hline Biological oxygen demand & 1443 \\
\hline Sodium & & 2860 \\
\hline Magnesium & & 569 \\
Calcium & $\mathrm{mg} / \mathrm{L}$ & 1258 \\
\hline Potassium & & 450 \\
Ammonium & & 11.26 \\
$\mathrm{Nitrates}$ & & 160 \\
$\mathrm{Chloride}$ & & 4.29 \\
$\mathrm{Cd}$ & & 0.15 \\
$\mathrm{Co}$ & & 0.25 \\
$\mathrm{Cr}$ & & 8.77 \\
$\mathrm{Cu}$ & & 0.75 \\
$\mathrm{Ni}$ & 0.46 \\
$\mathrm{~V}$ & & 0.19 \\
$\mathrm{~Pb}$ & & 5.9 \\
$\mathrm{Zn}$ & & 48.9 \\
\hline
\end{tabular}




\subsection{Pollution Indices}

Four indices were used to evaluate trace metal contamination in soils. The contamination factor $(C F)^{35}$ was calculated as a ratio between a particular metal concentration and the background levels that are shown in Table 6 and provided by South Africa's Department of Environmental Affairs ${ }^{36}$, using Eq. (1).

$$
C F=\frac{C_{H m}}{C_{\text {normal }}}
$$

where, $C F$ is the contamination factor, $C_{H m}$ is the mean concentration of a specific heavy metals and $C_{\text {normal }}$ represented background values by DEA. ${ }^{36}$

Table 6. Background levels of assayed trace metals (DEA 2013)

\begin{tabular}{lllllllll}
\hline Trace metal & $\mathrm{Cd}$ & $\mathrm{Co}$ & $\mathrm{Cr}$ & $\mathrm{Cu}$ & $\mathrm{Ni}$ & $\mathrm{V}$ & $\mathrm{Pb}$ & $\mathrm{Zn}$ \\
\hline Background values $\left(\mathrm{mg} \mathrm{kg}^{-1}\right)$ & 7.5 & 300 & 6.5 & 16 & 91 & 150 & 20 & 240
\end{tabular}

Table 7. Criteria for soil classification using pollution indices

\begin{tabular}{llll}
\hline Index Method & Values & \multicolumn{1}{c}{ Class } & References \\
\hline$C F$ & $<1$ & Low contamination & 35 \\
& $>1-3$ & Moderate contamination & \\
& $>3-6$ & Considerably high contamination & 37 \\
$I_{\text {geo }}$ & $>6$ & Very high contamination & \\
& $<0$ & Not polluted & \\
& $0-1$ & Not polluted-moderately polluted & 38 \\
& $>1-2$ & Moderately polluted & \\
& $>2-3$ & Moderately-strongly polluted & 20 \\
& $>3-4$ & Strongly polluted & \\
$P L I$ & $>4-5$ & Strongly-extremely polluted \\
& $<5$ & Extremely polluted & \\
& $>1$ & Not polluted & \\
& $<7$ & Polluted & \\
& $7 \leq P D \leq 14$ & Mow contamination \\
& $14 \leq P D<28$ & Considerably high pollution \\
& $\geq 28$ & Very high pollution & \\
\hline
\end{tabular}

Geoaccumulation index ( $\left.I_{g e o}\right)$ was used to evaluate trace metals' contamination due to anthropogenic changes by applying a constant to rectify their lithologic sources ${ }^{37}$ and was calculated as shown in Eq. (2).

$$
I_{\text {geo }}=\log _{2} \frac{C_{H m}}{1.5 \times C_{\text {normaL }}}
$$

where;

$I_{g e o}$ is the geoaccumulation index and 1.5 is a natural constant.

Pollution load index ( $P L I)$ was quantified using Eq. (3):

$$
P L I=(C F 1 \times C F 2 \times C F 3 \ldots C F n)^{1} / n
$$


where;

$P L I$ is the pollution load index and $n$ represented the number of assayed trace metals

These three single indices calculated from individual concentrations of metals in soils have been used to classify soils and sediments based on their pollution extent. ${ }^{10-11,23,38}$

Pollution degree $(P D)$, an integrated contamination index was calculated as a sum of contamination factors of individual trace metals. ${ }^{35,38}$

Soils were classified using these pollution indices as outlined in Table 7.

\subsection{Statistical Analysis}

Descriptive statistics: mean, standard error $(S E)$, standard deviation $(S D)$, minimum, maximum and coefficient of variation $(\mathrm{CV})$ described trace metal content in the sampled soils. Pearson's correlation coefficient, which is a measure of association strength between two variables interrelated pairs of trace elements. ${ }^{40}$ The method involved assessing the linearity between any two trace elements and showed a probability of common origin of these pollutants. Relationships and patterns of trace elements were assessed using two multivariate statistical approaches; principal component analysis $(P C A)$ and cluster analysis $(C A) .{ }^{17}$ The latter categorized metals to classes based on their correlations while the former, transformed original values of trace metal concentrations to new variables known as principal components and factor loadings. Cluster analysis was done using Euclidian distances and Ward's method as the criteria to form clusters while $P C A$ was displayed as factor loadings and Eigen values using a biplot. ${ }^{41}$ These two approaches are widely used to establish relationships in trace element contamination of soils. ${ }^{18,25}$ Data analysis was conducted using XLSTAT software at a $\mathrm{P}<0.05$ significance level.

\section{Acknowledgement}

The authors would like to thank the anonymous referees for constructive comments on earlier version of this paper. 


\section{References}

1. Slavkovic L., Skrbic B., Miljevic N., and Onjia A. (2004) Principal component analysis of trace elements in industrial soils. Environ. Chem. Lett., 2 105-108.

2. Sekabira K., Oryem Origa H., Basamba T., Mutumba G., and Kakudidi E. (2010) Assessment of heavy metal pollution in urban stream sediments and its tributaries. IJEST., 7 435-446.

3. Kodom K., Preko K., and Boamah D. (2012) X-ray fluorescence (XRF) analysis of soil heavy metal pollution from an industrial area in Kumasi, Ghana. Soil and Sediment Contam., 21 1006-1021.

4. Muchuweti M., Birkett J., Chinyanga E., Zvauya R., Scrimshaw M., and Lester J. (2006) Heavy metal content of vegetables irrigated with mixture of wastewater and sewage sludge in Zimbabwe. Implications for human health. Agr. Ecosyst. Environ., 112 41-48.

5. Radu T., and Diamond D. (2009) Comparison of soil pollution concentrations determined using AAS and portable XRF techniques. J. Hazard. Mater., 171 1168-1171.

6. Bernard M., and Darkoh K. (2009) An overview of environmental issues in Southern Africa. Afr. J. Ecol., 47 93-98.

7. Peinado F., Ruano S., Bagur Gonzalez M., and Estepa Molina C. (2010) A rapid field procedure for screening trace elements in polluted soil using portable X-ray fluorescence (PXRF). Geoderma., 159 76-82.

8. Towett E., Shepherd K., and Cadisch G. (2013) Quantification of total element concentration in soils using total X-ray fluorescence spectroscopy. Sci. Total Environ., 463 374-388.

9. Lu S., and Bai S. (2010) Contamination and potential mobility assessment of heavy metals in urban soil of Hangzhou, China: relationship with different land uses. Environ. Earth Sci., 60 1481-1490.

10. Dolezalova H., and Pavlovsky J. (2017) Indices of soil contamination by heavy metalsmethodology of calculation for pollution assessment (mini-review). Environ. Monit. Assess., 189 616.

11. Wu Q., Leung J., Geng X., Chen S., Huang X., Li H., Huang Z., Zhu L., Chen J., and Lu Y. (2015) Heavy metal contamination of soil and water in the vicinity of an abandoned e-waste recycling site: implications for dissemination of heavy metals. Sci. Total Environ., 506 217-225.

12. Kelepertzis E. (2014) Accumulation of heavy metals in agricultural soils of Mediterranean: Insights from Argolida basin, Peloponnese, Greece. Geoderma., 221-222 82-90.

13. Ma L., Sun J., Yang Z., and Wang L. (2015) Heavy metal contamination of agricultural soils affected by mining activities around Ganxi River in Chenzou, Southern China. Environ. Monitor. Assess., 187731.

14. Tang J., Chai L., Li H., Yang Z., and Yang W. (2017) 10-year statistical analysis of heavy metals in river and sediment in Hengyang segment, Xiangjiang river basin, China. Sustainability., 101057.

15. Norman N. (2013) Geology off the beaten track: Exploring South Africa's hidden treasures. South Africa, Penguin Random House, South Africa.

16. KanmanI S., and Gandhimathi, R. (2013) Assessment of heavy metal contamination in soil due to leachate migration from an open dumping site. Appl. Water Sci., 3 193-205.

17. Chandrasekaran A., Ravisankar R., Harikrishnan N., Satapathy K., and Prasad, M. (2015) Multivariate statistical analysis of heavy metal concentration in soils of Yelagiri hills, Tamilnadu, India-spectroscopical approach. Spectrochim. Acta. A. 137 589-600.

18. Pujiwati A., Nakamura K., Watanabe N., and Komai T. (2018) Application of multivariate analysis to investigate the trace element contamination in topsoil of coal mining district in Jorong, south Kalimantan, Indonesia. Earth Environ. Sci., 118:1-9.

19. Ma W., Tai L., Wang K., Fu L., Zhong Z., Qiao G., Chen Y., Yan B., and Cheng Z. (2017) Assessment of heavy metals contamination in soil: the impact of MSWI. Proceedings Sardinia / Sixteenth International Waste Management and Landfill Symposium/ 2 - 6 October, CSICA, Italy.

20. Shokr M., El Baroudy A., Fullen M., El-Beshbeshy T., Ramadan A., Halim, A., Guerra A., and Jorge M. (2016) Spatial distribution of heavy metals in the middle Nile delta of Egypt. ISWCR., 4 293-303. 
21. Long Y., Shen D., Wang H., Lu W., and Zhao Y. (2011) Heavy metal source analysis in municipal solid waste (MSW): Case study on Cu and Zn. J. Hazard. Mater., 186 1082-1087.

22. Han X., Lu X., Qinggeletu Q., \& Wu Y. (2017) Health risks and contamination levels of heavy metals in dusts from parks and squares of industrial city in semi-arid area of China. Int. J. Env. Res. Pub. Health., 14886.

23. Chai Y., Guo J., Chai S., Cai J., Xue L., and Zhang Q. (2015) Source identification of eight heavy metals in grassland soils by multivariate analysis from the Baicheng-Songyuan area Jilin province, Northeast China. Chemosphere., 134 67-75.

24. Yildirim G., and Tokalioglu S. (2016) Heavy metal speciation in various grain sizes of industrially contaminated street dust using multivariate statistical analysis. Ecotox. Environ. Safe., 124:369-76.

25. Kurt M. (2018) Comparison of trace element and heavy metal concentrations of top and bottom soils in a complex land use area. Carpath. J. Earth Environ. Sci., 13 47-56.

26. Fadigas F., Sabrinho N., Anjos L., and Mazur N. (2010) Background levels of some trace elements in weathered soils from the Brazilian northern region. Sci. Agri., 67 53-59.

27. Iqbal, J., and Shah, M. (2011) Distribution, correlation and risk assessment of selected metals in urban soils from Islamabad, Pakistan. J. Hazard. Mater., 192 887-898.

28. Khair S., and Rafizul S. (2018) Application of multivariate and geostatistical approaches in analysis and assessment of heavy metal sources in soil of waste disposal site at Khulna. Proceedings of the $4^{\text {th }}$ International Conference on Civil Engineering for Sustainable Development (ICCESD 2018), 9-11 February, KUET, Khulna, Bangladesh.

29. Dookhi N., Jewskiewitz S., and Jewaskiewitz, B. (2015) East London Regional (Roundhill) waste disposal site- wasting no time on the road to compliance. Civ. Eng., 23 35-41.

30. Jewaskiewitz S., and Dookhi N. (2017) Roundhill restoration. IMESA., 42: 63-66.

31. Chigor V., Sibanda T., and Okoh A. (2013) Studies on the bacteriological qualities of the Buffalo River and three water dams along its course in the Eastern Cape province of South Africa. Environ. Sci. Pollu. Res., 20 4125-4136.

32. Battaglia M. (2011) Encyclopaedia of survey research methods. Sage Publications Inc, Thousand Oaks, California.

33. Sampath D. (2005) Sampling; theory and methods. Statistical Publishing Society Calcutta, India.

34. Wines H., and Luther J. (2014) The effects of moisture on X-ray fluorescence spectrometry. 2014. [Access 27.3.2019] Available at: http://southriverscienceteam.org/news/documents/Posters/Wines_Student_Paper_Battelle.pdf

35. Hakanson L. (1980) An ecological risk index for aquatic pollution control: a sedimentological approach. Water Research., 14 975-1001.

36. Department of Environmental Affairs (DEA) (2013) National Environmental Management, Waste Act, 2008. National norms and standards for the remediation of contaminated land and soil quality in the republic of South Africa. Government Gazette, No. 36447, Pretoria, South Africa.

37. Muller G. (1969) Index of geoaccumulation in sediments of the Rhine River. GeoJournal., 2 108118.

38. Tomlinson D., Wilson J., Harris C., and Jeffrey D. (1980) Problems in the assessment of heavymetal levels in estuaries and the formation of a pollution index. Helgolander Meeresunters., 33 566575.

39. Ke X., Gui S., Huang H., Zhang H., Wang C., and Guo W. (2017) Ecological risk assessment and source identification for heavy metals in surface sediment form Liaohe River protected area, China. Chemosphere., 175 473-481.

40. Li X., Liu L., Wang Y., Luo G., Chen X., and Yang, X. (2013) Heavy metal contamination of urban soil in an old industrial city (Shenyang) in Northeast China. Geoderma., 192 50-58.

41. Morrison D. (1990) Multivariate statistical methods. $3^{\text {rd }}$ ed, McGraw-Hill Inc, New York. 
(C) 2020 by the authors; licensee Growing Science, Canada. This is an open access article distributed under the terms and conditions of the Creative Commons Attribution (CC-BY) license (http://creativecommons.org/licenses/by/4.0/). 